\title{
Mediastinal Mixed Non-Seminomatous Germ Cell Tumor
}

National Cancer Institute

\section{Source}

National Cancer Institute. Mediastinal Mixed Non-Seminomatous Germ Cell Tumor. NCI

Thesaurus. Code C6444.

An extragonadal non-seminomatous malignant germ cell tumor that arises from the mediastinum and is composed of two or more germ cell tumor types. It manifests with respiratory distress, thoracic pain, cough, superior vena cava syndrome, or hoarseness. 